\title{
HUNGARIAN ARCHAEOLOGY
}

\section{THE EXCAVATION OF AN EARLY MODERN CEMETERY IN SZÉCSÉNY}

\author{
Csilla Líbor - Virág LaczKó - Emese Zsiga-CsoltKó - Tekia Balogh Bodor \\ Hungarian Archaeology vol. 9 (2020), Issue 1, pp. 30-35, https://doi.org/10.36338/ha.2020.1.7
}

In the downtown area of Szécsény, there have been several excavation projects in the past few years, including those carried out primarily in connection to the medieval church, or others, which concerned the medieval settlement. In July 2019, the Heritage Protection Directorate of the Hungarian National Museum conducted a preventive excavation in Szécsény, at 4 Kossuth street. The site was situated a couple of hundred meters away from the medieval part of the town, to the south from it, very close to the present-day downtown area (Fig. 1). Hundreds of graves have been found, - a part of a cemetery -, dating from the early modern period, which is otherwise less well represented in the archaeological record of towns in Hungary, as only a few cemeteries could have been excavated thus far. Consequently, the finds and the archaeological observations point far beyond their local historical significance.

Excavation in the area was made possible by the condition that during the years there have been many investments in this part of the town, yet, the site was not built up, but only covered with concrete, functioning as a parking lot. However, the layers must have been apparently disturbed, as there were no preventive

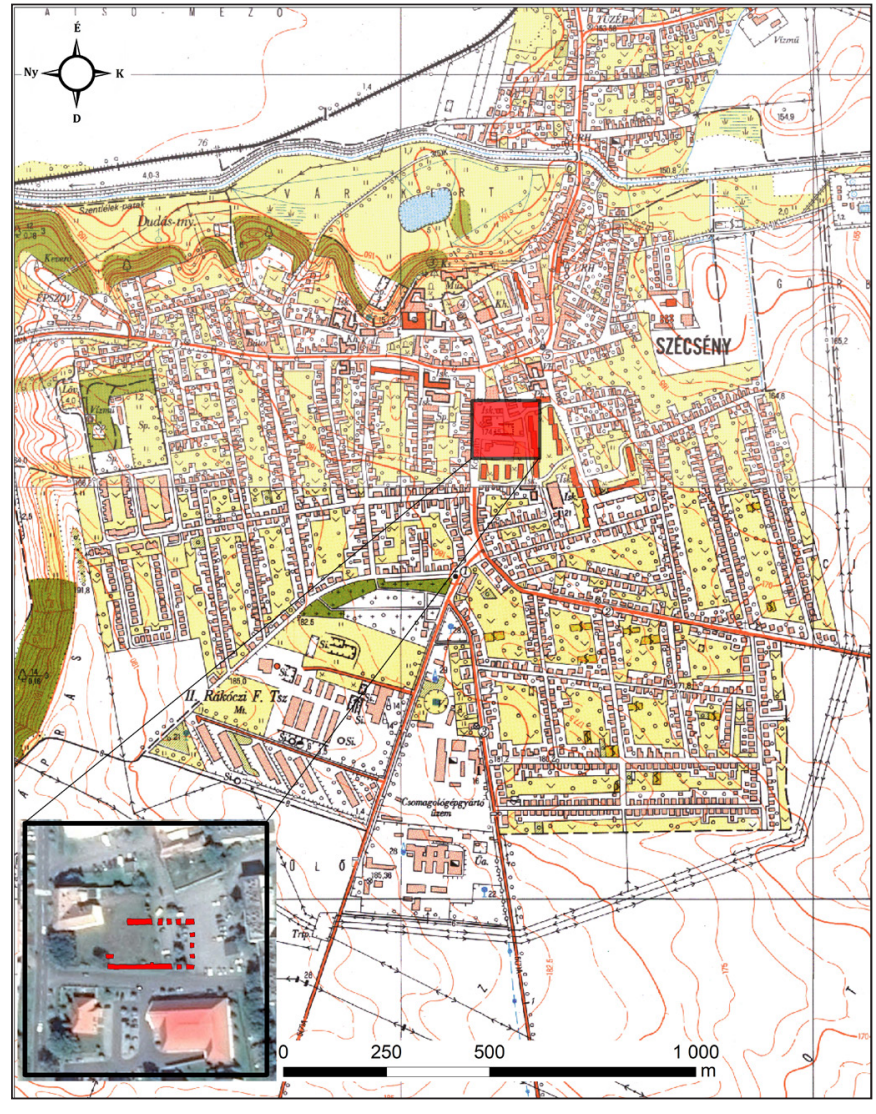

Fig. 1. The excavation area in Szécsény archaeological excavations taking place prior to previous constructions of public utilities. Such disturbances had been reported during the 19th century as well, yet, no archaeological documentations survive.

\section{RESEARCH HISTORY}

Ferenc Kubinyi was the first to report about the cemetery, of which a fragment had been unearthed during the construction of cellars in the 1860s (GALCSIK, 2010, 158). He also reported several finds, which he was able to date to the 16th century, except for this, however, there is no further information recorded about them (IPOLYI, 1963, 22). At the end of the 1900s, there were constructions in the area, and again, the graves were disturbed - an infant grave has been discussed in detail by Tamás Majcher in 1992 (MAJCHER, 1993).

In 2009, preventive excavations took place prior to the construction of the Penny Market at the corner of Kossuth Lajos and Sas streets. The excavation was conducted by the staff of the Kubinyi Ferenc Museum, directed by Krisztián Zandler, and the results have been published in an MA thesis submitted by Kinga Bercsényi at the Eötvös Loránd University (BERCSÉNYI, 2011).

\section{THE 2019 EXCAVATION OF THE CEMETERY FRAGMENT}

Our excavation took place in the middle and northeast segments of the site (Fig. 2). The archaeology was only partially affected by the construction of 28 pillars, which were to support the sports hall of the school. In fact, approximately 2,4 by 3,5 $\mathrm{m}$ large and $2 \mathrm{~m}$ deep foundation trenches were excavated for the pillars. 


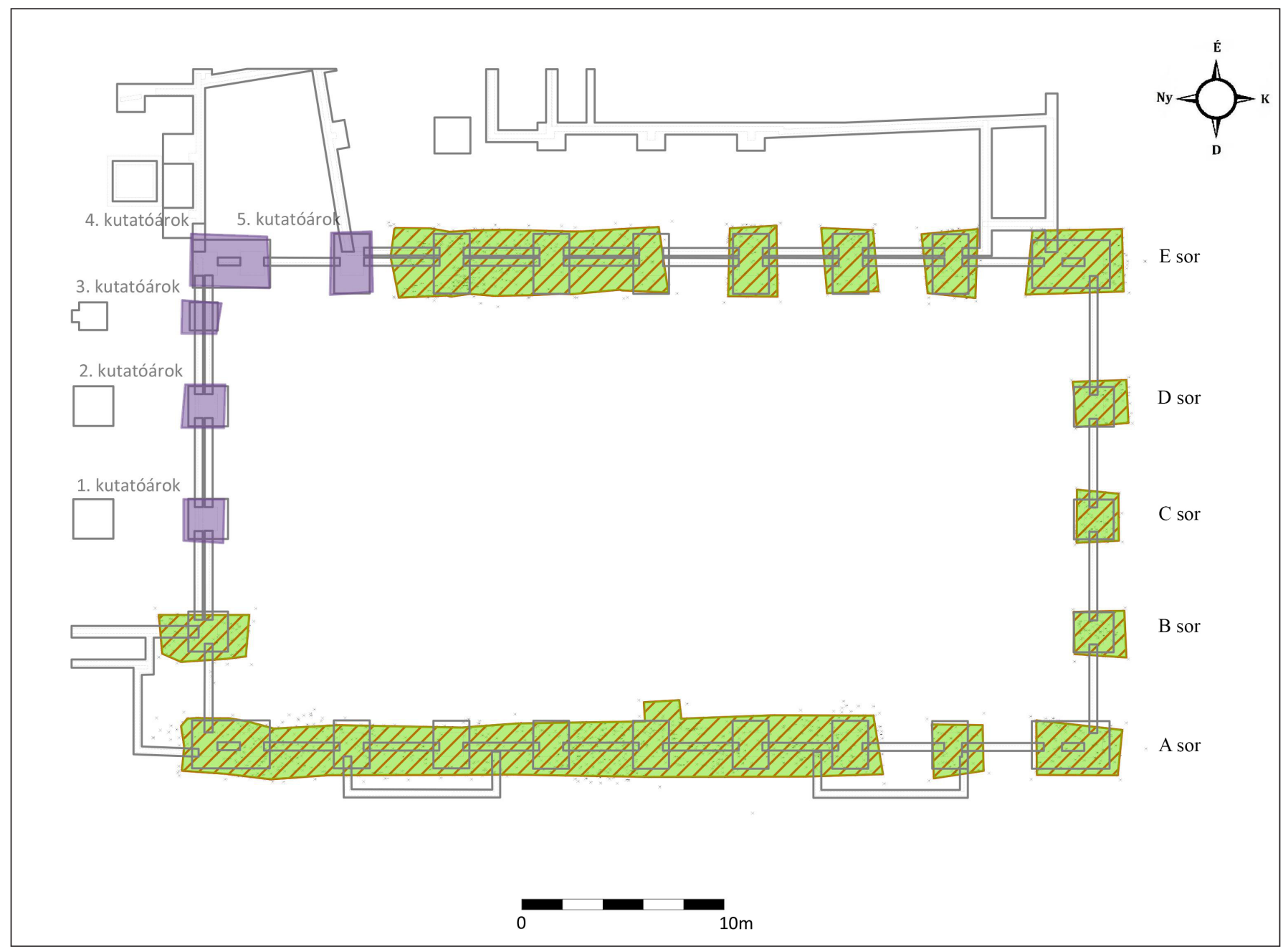

Fig. 2. The 2019 excavation. Purple: test excavation by Tünde Horváth; green: rescue excavation by HNM-HPD

Trial trenching was carried out in 2019, by Tünde Horváth, a representative of the Dornyay Béla Museum. In June 2019, we continued to excavate 23 foundation pits, in which 286 graves and two other features could be registered altogether. There were graves found in each pit, but the intensity of the burials was different. The pits in row "A" were relatively crowded with graves, in 4-5 different layers, while in row "E" there were sometimes only one or two layers documented. It became clear during the excavation that the location of the sports hall completely overlaps with the site of the cemetery.

With a very few exceptions, the graves were oriented W-E. Due to the intensity of the burials, the number of intact graves was relatively low as they were often in superposition, cutting one another. Thus, many of them were found "disturbed", furthermore, in the upper layers, we were usually not able to find the edges of the grave pits. However, we could often document bones in secondary position (in small heaps or as scatter finds), which suggested that there could be once some buildings standing in this area as well, which disturbed the graves.

In most graves, the coffins were preserved in excellent condition and the dendro samples will be hopefully analysed in the near future. We were able to recover one of the coffin lids almost fully intact, on which we could also document a decorative pattern made of bronze rivets, forming a spiral shape.

Despite the good preservation of the coffins, the bones were extremely poorly preserved in approximately $80 \%$ of the graves, often degraded into dust. In a few - yet unexplained - cases, however, full skeletons could be excavated, which were in good condition. The question arises, whether the wooden coffins, the interior coating of the coffins, the geochemical character of the soil, or the urban conditions explain the generally poor preservation of the bones. 
To this date, there have been no detailed anthropological assessment prepared, but the large number of infant-subadult graves might well fit into the picture of the mortality of early modern populations (LíBor, 2018). As only a fragment of the cemetery could be excavated, the perspectives of our analysis are unfortunately very limited.

\section{FINDS}

The cemetery is relatively rich in finds and this essentially reflects early modern trends. Among the 286 graves excavated, there were altogether 37, where decorated headdresses could be documented, and there were 6 other finds, which were identified as scatter finds and could belong to any of the already documented cases, or to others, which remain yet unidentified. With a few exceptions, all of them were found in good condition (Fig. 3).

In five graves, we found headdresses with flower medallions, in nine cases, these objects or their remains were framed with braided metal wires. In two cases, their decoration was composed exclusively from braides, laces and beads (or at least other decorative elements could not be documented). In most cases, the headdresses were decorated with beads, spangles, and possibly with petals made of garnet stones, composed into various patterns. Two of these objects featured also decorations made of metal wires. In two graves, the headdresses were of unique design.

Dress accessories were found in several graves. From three graves, well preserved upper parts of outer garments could be collected - they were made of yarns containing metal wires and we will be, hopefully, able to reconstruct the full garments based on them. In three other graves, leather remains and metal parts of shoes were recovered. In 11 cases, we found setts of clasp fasteners and buttons, and their position in the grave (arranged in rows) will yield significant data concerning the reconstruction of the garments (Fig. 4).

Jewelleries, hairpins and rings were also found in many graves. There have been altogether 20 hairpins recovered, in most cases they had undecorated small globular heads, and in some cases larger heads decorated with granulations. Found on two sides of a skull, a pair of gilded silver hairpins, inlaid with garnet stones were unique finds in Grave 12. The

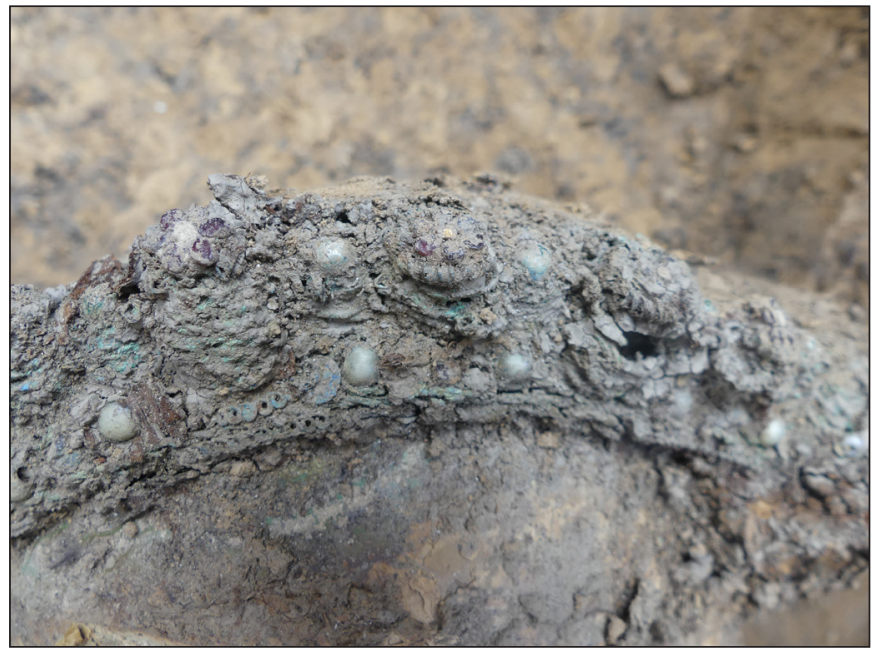

Fig. 3. Headdress with flower medallions from Grave 205

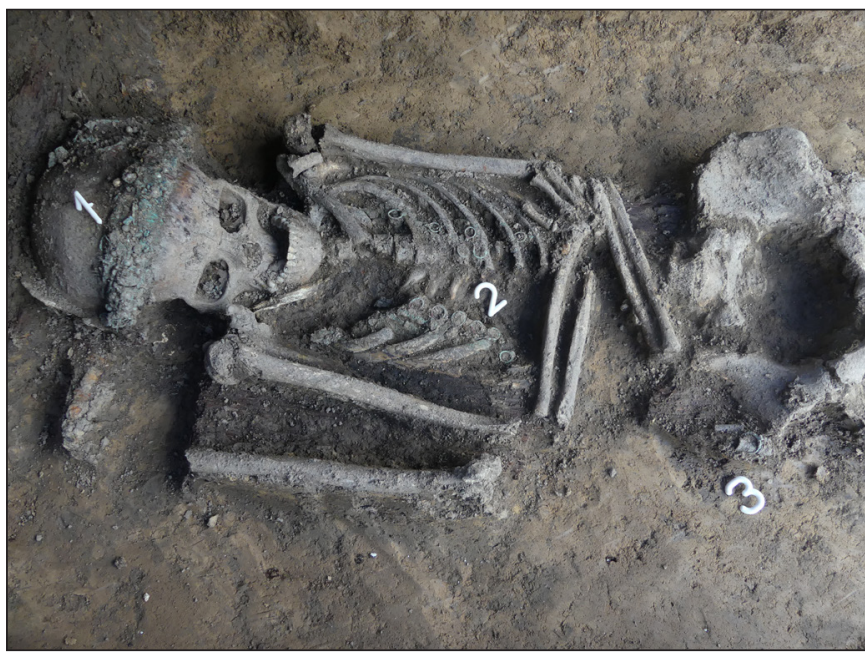

Fig. 4. Grave 259. Grave goods: 1: headdress, 2: metal wires of a corset, 3: ring inlaid with stones

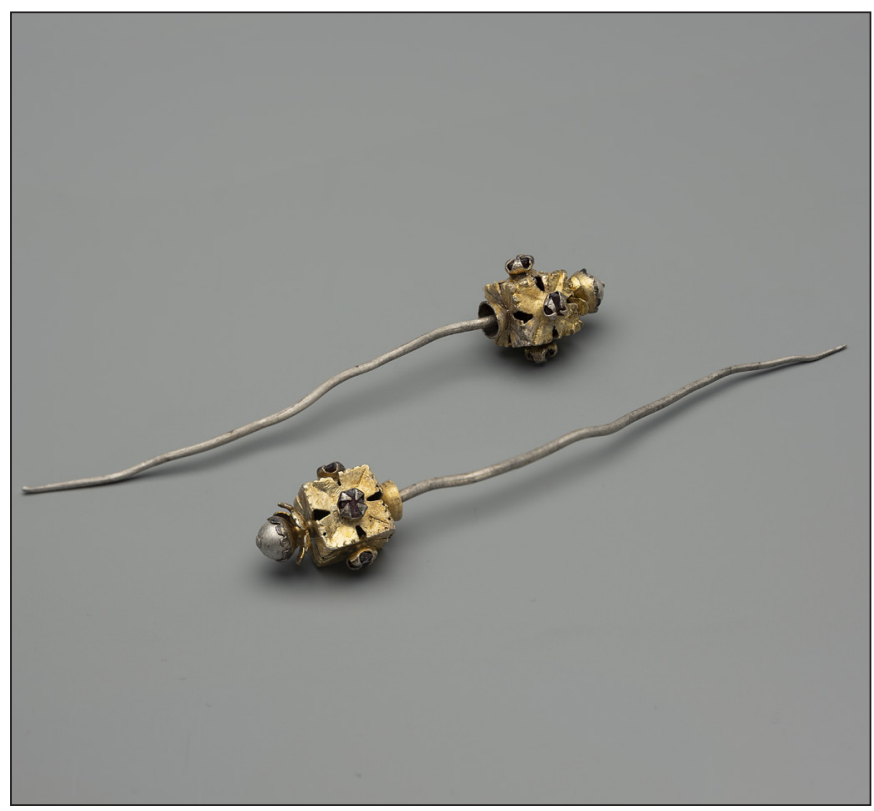

Fig. 5. Gilded silver hair pin with garnets, Grave 12 (photo by József Bicskei) 
pins were made of silver, to the end of which traced silver cubes inlaid with garnet stones were applied, soldered to the top of the pins with small globular heads surrounded by petals (Fig. 5). A large hair clip, as well as a fragment of a hair-knot pin with circular base were also connected to hairdressing. found.

Most of the rings we found were simple precious metal rings, and there were only a few elaborate ones. The most beautiful piece in the assemblage was a gilded cast silver ring inlaid with stones - probably garnets (Fig. 6). The head of the ring consists of four small polished garnet stones sitting in separate bezels arranged in a rectangle. The four main corners of the rectangle are held by leaf shaped claws, and at the sides and at the top of its head there are altogether five loops and pendants, hanging from each, each holding another small stone. Lately, one of the pendants was lost.

Many of the finds represent Christian religious practices, e.g. rosary beads, lead crosses, religious coins were also found in the graves. A particularly interesting find was a gilded medallion locket with a bone fastener inside. The locket was unfortunately opened during the excavation; however, it contained a folded fragment of a printed German language bible (Fig. 7).

Thus far, most of the coins were found in children's graves. Since they were heavily corroded, it was unfortunately impossible to identify them on the spot - before restoration. In line with earlier results, this cemetery fragment can be dated to the early modern period (BERCSÉNYI, 2011, 52-54). It likely dates back to much earlier than the time of Maria Theresa, when burials were pushed out of town, however, it seems that it was still used in the middle years of the 1700 s.

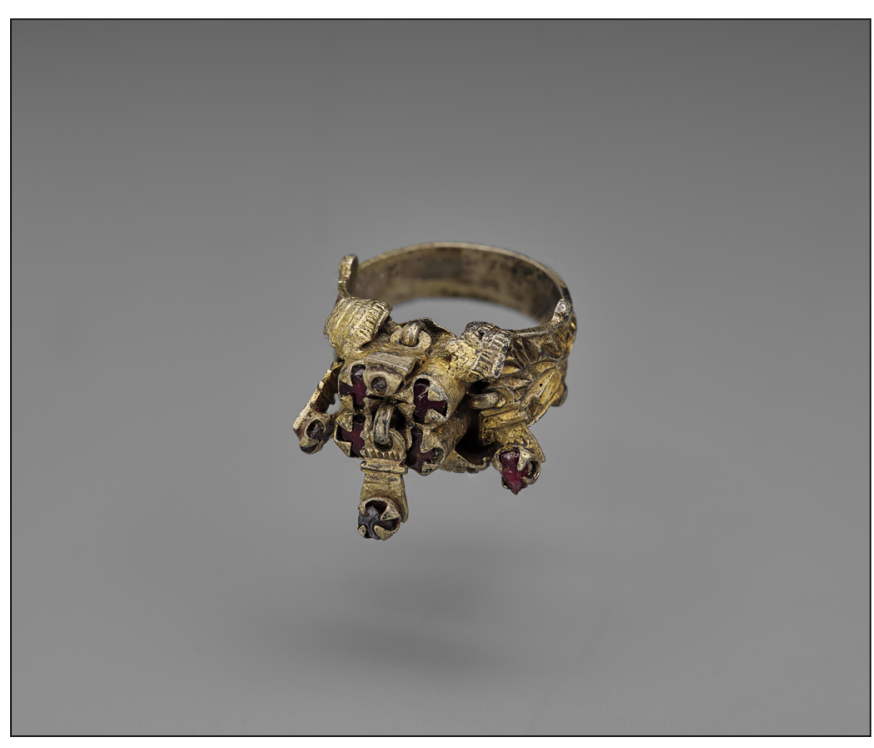

Fig. 6. Gilded cast silver ring inlaid with garnets, Grave 44 (photo by József Bicskei)

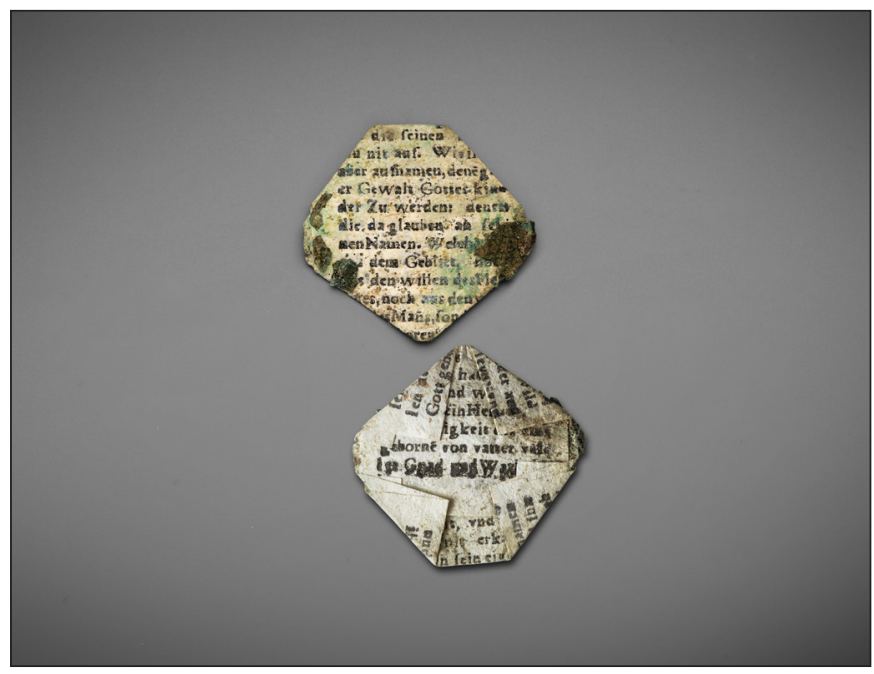

Fig. 7. Printed Bible fragment from a medal (photo by József Bicskei). Modern translation: „He came to that which was his own, but his own did not receive him. Yet to all who did receive him, to those who believed in his name, he gave the right to become children of God-children born not of natural descent, nor of human decision or a husband's will, but born of God" (John 1, 11-13)

Some of the graves were whitewashed, and from

historical records we know of major pest outbreaks and other epidemics in the 1680 s, when the cemetery must have been already in use. Prior to the full assessment of the finds, the results discussed so far date the use of this part of the cemetery between the late 1600s and before the $1750 \mathrm{~s}$.

\section{SUMMARY}

In summary, the excavated fragment of the cemetery was rich in finds, which were generally well preserved. We assume that the assessment of the materials will provide potentially new data regarding this period, which is generally far from being thoroughly researched.

It has been suggested previously that the most intensive part of the cemetery is the area of the 2009 excavation, however, there were only 120 graves documented there in 2009 , within an area of 525 sq metres 
(BERCSÉNYI, 2011, 19-20), and we have excavated altogether 286 graves, within an area half as large. This difference might as well be explained by the different documentation method (numbering of features), as we assigned separate ID numbers also to individual skulls and completely empty graves.

The area of the cemetery clearly did not end at the boundary of the construction site. Towards the northern corner of the site, the burials were less intensive, however, the cemetery continued that way. Based on earlier documentations, 100 metres north from the site of the Palóc Áruház - a local supermarket -, there were some bones found, which suggests that the area of the cemetery could have extended to this direction as well (BERCSÉNYI, 2011, 18). The more intensive parts could have been situated rather to the south from the presently excavated area, towards the building of the Penny Market. To the west, the Kossuth street could have been a possible boundary. To the south, the cemetery area could have ended at the Magyar street, as suggested by Kinga Bercsényi based on Krisztián Zandler's results (BERCSÉNYI, 2011, 17-214).

\section{ACKNOWLEDGMENTS}

We would like to express our gratitude to Krisztián Sebe (Jánosik Ltd), Tünde Horváth, and Szilvia Guba (Kubinyi Ferenc Museum).

\section{RECOMMENDED READINGS}

Lengyel, B. (2019). Pártás kislány a hódoltság korából. A gödöllői párta rekonstrukciója [Fetiţa cu cunună din epoca ocupației otomane. Reconstrucția cununii din Gödöllö]. Erdélyi Magyar Restaurátor Füzetek 19, $19-26$.

Mérai, D. (2008). Ethnic and social aspects of clothing: The archaeological evidence in Early Modern Hungary. Annual of Medieval Studies at the CEU 14, 81-107.

Mérai, D. (2010). "The True and Exact Dresses and Fashion”: Archaeological Clothing Remains and their Social Contexts in Sixteenth- and Seventeenth-century Hungary. Archaeolingua Central European Series 5. Budapest: Archaeolingua.

Ritoók, Á. \& Simonyi, E. (2005). „... a halál árnyékának völgyében járok”: A középkori templom körüli temetők kutatása. Opuscula Hungarica 6. Budapest: Magyar Nemzeti Múzeum.

Zay, O. (2015). „,Tegnap még lány vala, most immár kontya vagyon”: Női haj- és fejviseletek a kora újkorban [„Gestern was sie Mädchen, jetzt trägt sie nummehr einen Dutt”: Haar- und Kopftrachten der Frauen in der Frühneuzeit]. In Szőllősy Cs. \& Pokrovenszki K. (eds.), Fiatal Középkoros Régészek VI. Konferenciájának Tanulmánykötete (pp. 205-222). Székesfehérvár: Szent István Király Múzeum.

\section{REFERENCES}

Bercsényi, K. (2011). Szécsény kora újkori temetője (MA Thesis). Eötvös Loránd University, Budapest.

Galcsik, Zs. (2010). Kubinyi Ferenc jelentése az 1862-ben Szécsényben és környékén talált régiségekről. In Szenográdi F. (ed.), Szécsényi kalendárium a 2010-es esztendőre. Szécsény.

Ipolyi, A. (1863). Magyar régészeti krónika. Archaeologiai Közlemények 3, 169-179. 
Csilla Libor et al $\bullet$ The Excavation of an Early Modern Cemetery in Szécsény

Líbor, Cs. (2018). Mit mesélnek nekünk a gyermeksírok? Balatonszárszó-Kis-erdei-dűlő középkori temetőjének példája alapján [What's the story of children from medieval times?]. In A Fiatal Középkoros Régészek VIII. Konferenciájának Tanulmánykötete (pp. 95-107). Sátoraljaújhely: Petőfi Irodalmi Múzeum - Kazinczy Ferenc Múzeum.

Majcher, T. (1993). Szécsény közigazgatási egység középkori régészeti topográfiája (MA Thesis). Eötvös Loránd University, Budapest. 